\title{
Correction: in the wild hybridization of annual datura species as unveiled by morphological and molecular comparisons
}

\author{
loannis T Tsialtas ${ }^{* *}$, Efstathia Patelou ${ }^{2}$, Nikolaos S Kaloumenos ${ }^{3}$, Photini V Mylona ${ }^{4}$, Alexios Polidoros²,
} Georgios Menexes ${ }^{1}$ and Ilias G Eleftherohorinos ${ }^{1}$

\section{Correction}

After the publication of this work [1], it was brought to the author's attention that in the sentence "Genus Datura, family Solanaceae, consists of nine (annual and tree) species, originating from the New and Old World [1]", "originating from" should be replaced with "present in". We regret any inconvenience that this inaccuracy may have caused.

\begin{abstract}
Author details
${ }^{1}$ Faculty of Agriculture, Laboratory of Agronomy, Aristotle University of Thessaloniki, 54124 Thessaloniki, Greece. ${ }^{2}$ Faculty of Agriculture, Laboratory of Genetics and Plant Breeding, Aristotle University of Thessaloniki, 54124 Thessaloniki, Greece. ${ }^{3}$ Biological Sciences, Syngenta, Jealott's Hill International Research Centre, Bracknell, Berkshire RG42 6EY, UK. "ELGO-“Demetra", Agricultural Research Center of Northern Greece, 57001 Thermi, Greece.
\end{abstract}

Received: 16 October 2014 Accepted: 16 October 2014

Published: 7 November 2014

\section{Reference}

1. Tsialtas IT, Patelou E, Kaloumenos NS, Mylona PV, Polidoros A, Menexes G, Eleftherohorinos IG: In the wild hybridization of annual Datura species as unveiled by morphological and molecular comparisons. J Biol Res Thessaloniki 2014, 21:11.

\section{doi:10.1186/2241-5793-21-18}

Cite this article as: Tsialtas et al:: Correction: in the wild hybridization of annual datura species as unveiled by morphological and molecular comparisons. Journal of Biological Research-Thessaloniki 2014 21:18.

\footnotetext{
*Correspondence: tsialtas01@windowslive.com

${ }^{1}$ Faculty of Agriculture, Laboratory of Agronomy, Aristotle University of
} Thessaloniki, 54124 Thessaloniki, Greece

\section{Submit your next manuscript to BioMed Central and take full advantage of:}

- Convenient online submission

- Thorough peer review

- No space constraints or color figure charges

- Immediate publication on acceptance

- Inclusion in PubMed, CAS, Scopus and Google Scholar

- Research which is freely available for redistribution

Submit your manuscript at www.biomedcentral.com/submit

( Biomed Central 